\title{
Government Stimulus Policy Effects to Foster Indonesia's Economic Growth: Evidence from Seventeen Years' Experience
}

\author{
Agus Sriyanto ${ }^{1^{*}}$, Sri Murwani ${ }^{2}$, Eleonora Sofilda ${ }^{3}$ \\ 1,2Politeknik Keuangan Negara STAN, Indonesia \\ ${ }^{3}$ Universitas Trisakti, Indonesia \\ Email: 1judicialagus@gmail.com, ${ }^{2}$ srimurwani@pknstan.ac.id, ${ }^{3}$ eleonora_140872@yahoo.com
}

") Corresponding author

\section{JEL Classification:}

G18

O47

Received: 30 April 2020

Revised: 27 November 2020

Accepted: 22 December 2020

\begin{abstract}
We study the budget stimulus effects and government spending to help foster the recovery of Indonesia's current economic growth that was hit by the monetary crisis 1997 and 2008. Using government spending allocation policies through capital expenditures, infrastructure expenditures, financing through government debt, private debts, and increased productivity through export and import activities. This research provides to proves the extent to which macroeconomic variables could promote Indonesia's economic growth due to the crisis-using quantitative analysis of time series in the analysis of cointegration autoregressive distribution lag and bounds testing cointegration starting from 2001 Q4 to $2018 q 4$ data. We can prove that in the short term, the most influential factor in economic growth is the first lag of the GDP growth itself; The first lag of exports, and the first lag of government spending and imports. However, some factors still negatively affect corruption control, government effectiveness, and government debt. While in the long term, government expenditure and imports still have a positive effect, but corruption control is still hurt GDP.
\end{abstract}

\section{Keywords:}

government spending, debt, export, import, control of corruption.

\section{How to Cite:}

Sriyanto, A., Murwani, S., \& Sofilda, E. (2021). Government Stimulus Policy Effects to Foster Indonesia's Economic Growth (Evidence from Seventeen Years' Experience). Signifikan: Jurnal Ilmu Ekonomi, 10(1), 63- 76. doi: http://doi.org/10.15408/sjie.v9i2.15480. 


\section{Introduction}

In 2008-2009, Indonesia and other ASEAN countries experienced the U.S. financial crisis due to the subprime mortgage crisis after the previous year 1997 suffered a monetary crisis. The 2008-2009 financial crisis, in some cases, led to investment funds drawn from the United States to its home country to keep American banking liquidity, leading to the correction of economic and financial growth in countries with trade/Investment relations with the United States. The financial crisis is also not only in Southeast Asia but also in the European Monetary Union member states due to increasing government budgeting levels, and the accumulation of government debt levels began to impact private investments negatively (Afonso \& Aubyn, 2019).

As a public finance manager, the Ministry of finance started doing efficiency programs with reduced spending, increasing infrastructure budgets to improve public services. However, on the other hand, the government cannot do to raise the income from taxation to keep the stability of the economy (tax cut policy) and give private sector stimuli like subsidy and social security programs to recover again (see Dawson, 2006; Spilimbergo et al., 2008).

Figure 1. National account, expenditure, Gross Capital Formation GDP, to GDP Percent

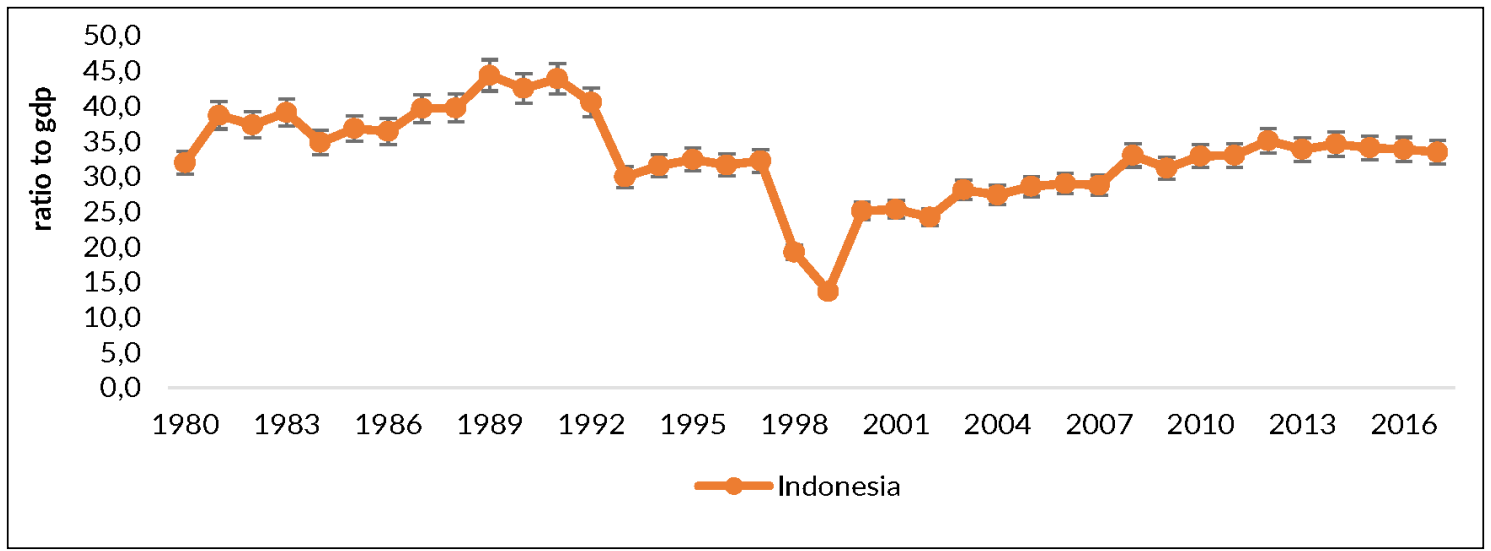

From some of the explanations above, the study tried to explain the empirical evidence and linkage between government spending, capital expenditure, and infrastructure spending. With the government's role in increasing inclusive growth because it has driven by a stimulus financial policy of government through three lanes: first economic infrastructure through four ministries/institutions, among others, Ministry PUPR, Ministry of Transportation, Ministry of ESDM, Non-Ministries/institutions, transfer to regional and financing. Secondly, through the social infrastructure of the Ministry of Education and Culture, the Ministry of Religion, and the third infrastructure support through BPN and the Ministry of Industry. We assume that increasing capital and infrastructure spending and government debt can improve capital formation to increase investment that will excite the business sector that can increase economic growth because it raises value-added. 
According to Greene \& Villanueva (1991), public sector investment in developing countries is a positive function of government investment level trend, reflected in sector investment Infrastructure. Furthermore, they also argue long-run complementary of private to public sector investment but in short-run substitutability (public sector investment appears to crowd out private sector investment).

To see the implications of some of the above views, the author investigates some of what things can improve private investment. According to Aizenman \& Marion (1993), high uncertainty in finance led to the decline of private investment in developing countries. Instead, according to Erenburg (1993), Private investments in the United States increased with increased private sector spending capacity. Also, the declining interest rates and net capital inflows from overseas developing countries would increase private investments, so they also advise if there is crowding out caused by government investment. It is necessary to enforce a ceiling on the banking system credit and net capital inflow to avoid the adverse effects of expansionary demand policies that result from the crowding out of private investment.

We also compare the implementation of a private capital role enhancement policy in some developed countries. Voss (2002) determines behavior in conducting private and government investments in developed countries in the United States and Canada. It is challenging to explain complementary functions among public and private investments; But, in terms of public investment, innovations tend to follow private investments. Furthermore, Korean countries' experience can have seen that through research Deok-Ki Kim \& Seo (2003), by analyzing the relationship between FDI, economic growth, and domestic investment. They found that FDI significantly affected domestic investment and economic growth; they also found that increasing domestic investment tends to cause FDI outflow. On the other hand, add the findings Deok-Ki Kim \& Seo (2003); otherwise, according to FDI, FDI will re-enter due to the significant factor of foreign capital or capital reserves, labor wages, and skilled workers' land availability.

To explain the development application of growth theory of the last five years, we tried to understand and measure the linkage between public and private investments to increase economic growth is crucial for developed and developing countries. Public investment is a part of public expenditure (usually calculated in allocating government budgets, e.g., capital expenditure and infrastructure spending) and economic decisions taken within the broader general financial framework.

At the same time, private capital is an addition to public capital. Public capital, together with private and human capital, labor, and technology, is a function of production factors/Cobb Douglas function. Public investment can have linked to the growth outlook, but according to the literature, differentiated between public capital and private capital influences both macroeconomic variables. The growth of private capital will always bring positive growth because of market efficiency and competition (Afonso \& Aubyn, 2019). However, on the other side of public capital in its implementation may be less efficient and effective, less competitive, and socially patterned so that it can be less competitive 
with private capital and foreign capital, see also Dreger \& Reimers (2016) and Cavalcanti et al. (2014). Public Investment in Indonesia has been made in several ways, such as capital expenditure and infrastructure expenditure.

Here are the results we have summarized some of the research in several countries and regions, developed and developing countries for the last five years in advance with the government spending function used to increase economic growth and Increase private investment.

The results of a summary of several previous empirical research in the last five years can have taken the following conclusions: Starting from Akram (2015) research that states to increase real GDP can use domestic debt but must have kept at a certain level to be sustainable. Further research on Zhang (2015) added that to increase productivity in the field of agriculture needs to has developed public investment, research and development on the other hand also open the market's most extensive and open investments to be able to foreign knowledge spillovers that are important to the developing world. The same year Sabry (2015) advised that the government increases bureaucratic efficiency and independence and higher regulatory quality to increase GDP.

Adding from previous research results in 2015, Amidu (2016) found that the degree of investment directed through person and institution into private housing is key to reducing financial volatility. Furthermore, Sasmal (2016) mentions the success of public expenditure on the improvement of CPMI, such as road, irrigation, power, transport, and communication, is higher; per capita earnings are also additionally greater. Public investments are more likely to increase growth than current public expenditure.

Further research results in the year 2017-2019 as follows Murova (2017) and Khanna \& Sharma (2018) start by looking at that to increase the growth is by increasing the effectiveness of the public area. Nguyen (2018) said the government is raising the capital stock. Da Rocha \& Saes (2018) recounted Brazil's success, attracting private agents to invest in transportation infrastructure. Furthermore, complementing Da Rocha \& Saes (2018) found that financing in roads, energy, and telecom sectors have the maximum positive impact on the GDP. Sabir (2019) also says that the level of growth needs to be done by restructuring taxation and incentive for business people to create new employment. Amusa (2019) added to increase productive spending and good governance, but on the other hand, Scott-Joseph \& Turner (2019) also reminded governments related to government debt could increase government costs and diminishing income sources.

The economic growth rate should increase so that the tax ratio for government budgets also increases and vice versa. To learn how GDP increases, we first studied the dynamic effects of government spending in capital expenditure and infrastructure expenditures, private debts, export and import values in encouraging increased GDP growth from the aggregate side of demand.

The rate of economic growth should increase with the increase in government debt, whether the government debt used to provide infrastructure (public goods) is still at a safe level or even burdening the country's finances. Furthermore, importation activities 
have been carried out to transfer the latest technology that is a condition of endogenous economic growth according to Romer (1994) in the medium and long term. Whether the effect on productivity increases, whether the value of exports can grow following the trade balance deficit or only in consumption alone without any increase in added value, then whether the existing bureaucracy has been efficient and accountable in managing its finances.

This study combines macroeconomic indicators and governance quality indicators included in one research model that has never been done before. Economic growth was driven from within by advancing human capital in the field of research and development, and increasing the role of the government in providing public goods that can help ease business, entrepreneurship, create job opportunities and increase investment. We first studied the dynamic effects of government spending in the form of capital expenditures and government infrastructure expenditures, government and private debt, the value of exports and imports included in the equation to answer whether macroeconomic variables have impacted the increase in economic growth as conveyed by Romer. Additionally, we also study incorporate data control on corruption (COC) as the instrument (moderating variables) carried out by the government to promote targeted economic growth because corruption can cause lowering public investment and then lowering economic growth Mauro (1995).

\section{Method}

This study uses an estimation method through the ARDL cointegration analysis from the previous research. We use the development variable theory of earlier studies that have been conducted by Nguyen (2018), Akram (2015), Amusa (2019), ScottJoseph \& Turner (2019), Ning et al. (2019), Sasmal (2016), Atabaev et al. (2018), and Muthu (2017). Macro variables with time-series data generally have stationary problems, so cointegration analysis is used to anticipate this. More specifically, this study uses the Bounds Testing Cointegration method with ARDL approach to the advantage that this method does not matter the variables in the model: I (0) or I (1). Tests conducted by Pesaran et al. (2001) showed that the ARDL approach would produce estimates consistent with long-term coefficients that are asymptomatically normal, even if the explanatory variables or regressors are already I (0) or I (1).

The first step to proving the effect of independent variables on our dependents is analyzed using ordinary OLS. Still, because some data time series is not stationary at the data level, we need an error correction model for short-term effects and continued cointegration tests to see the long-term relationship. There are three procedures in conducting the test: Data stationary Test (Unit Root Test, test cointegration, and forming error correction model from the residual equation cointegration. The ARDL approach of Pesaran et al. (2001) shows that the ARDL approach will generate estimates consistent with long-term coefficients. However, the details or Regressor variables are already I (0) or I (1). Estimating and identifying ARDL models can use Ordinary Least Square (OLS) when the ARDL order has been determined. 
In this paper, we contribute to applying the literature using ARDL analysis using the Ministry of finance data, Federal Reserve Bank of St. Louis, and World Government Indicator between 2002q4 and 2018q4 to generate the influencing factors as well as the impact values. In that context, we also calculate the return on public and private macroeconomic investments and assess the potential effects of 2008 before and after the economic and financial crisis, by comparison with the earlier shorter time-period research, which got after the crisis. In practice, we deal with investments in conventional private investment goods conducted by the public sector (or, more specifically, the government) or the private sector).

Figure 2. Estimation Model Based on Stationarity Test

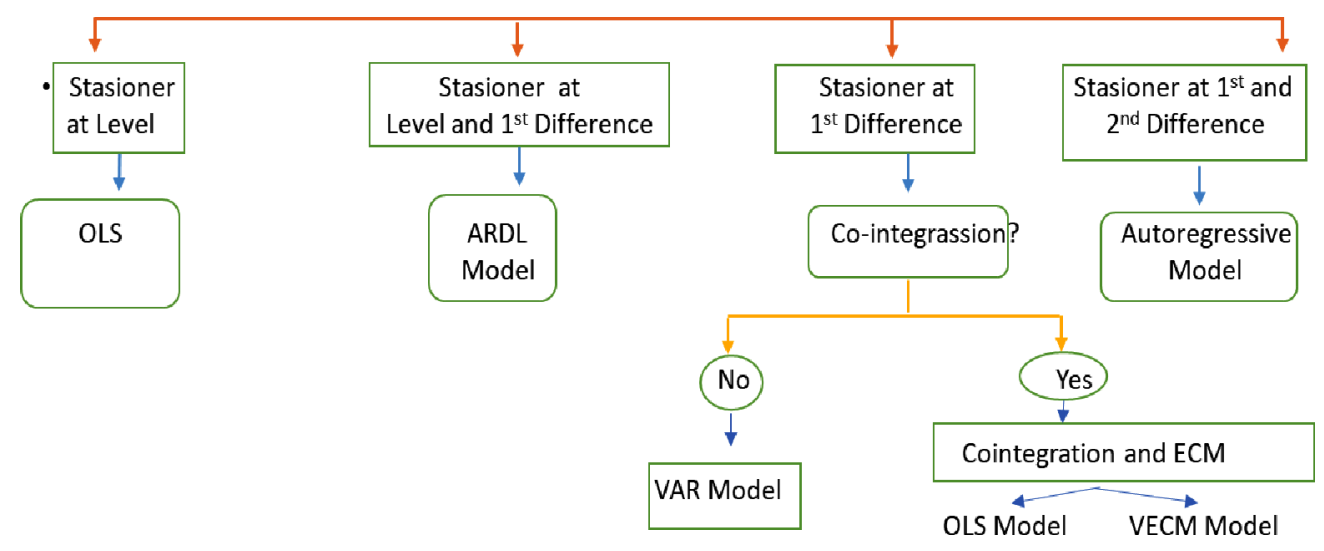

Source: Shrestha et al. (2018)

There are critical issues used to develop hypotheses. Whether government spending through capital expenditure and infrastructure expenditure (LNGOVEXP) has driven by an inclusive financial policy of government through three lanes are significant towards capital formation in economic development that has reflected an increase in GDP, for increasing GDP was also did by private participation in the form of capital and debt both domestically and internationally. Of course, the entire government and private programs are Government effectiveness of bureaucracy (LNGE) and corruption control (LNCOC), So we also include both variables. Based on the above exposure the ARDL equation used in this study was " $\mathrm{Y}_{\mathrm{t}}=\beta_{0}+\beta_{1} \mathrm{y}_{\mathrm{t}-1}+\ldots \ldots+\beta_{\mathrm{k}} \mathrm{y}_{\mathrm{t}-\mathrm{p}}+\alpha_{0} \mathrm{x}_{\mathrm{t}}+\alpha_{1} \mathrm{x}_{\mathrm{t}-1}+\alpha_{2} \mathrm{x}_{\mathrm{t}-2}$ $+\ldots \ldots . . .+\alpha_{\mathrm{q}} \mathrm{x}_{\mathrm{t}-\mathrm{q}}+\varepsilon_{\mathrm{t}}$ ", where $\varepsilon_{\mathrm{t}}$ is a random "disturbance" term.

\section{Results and Discussion}

The study ADF test at the level and first Difference of the variables to check the stationary level of data series. The unit root test results, given in Table 1, show that both variables are non-stationary at their levels but stationary at their first Difference. The process of processing the following research data is to know cointegration on the model using the ARDL Bound test method. The determination of the level of cointegration has done with the condition of critical value bounds, according to Pesaran 
et al. (2001). Before estimating the ARDL model, it takes several diagnostic tests to allow the estimated ARDL model to have spared from the breach of the correlation assumptions, the specification of the function (specification error), normality, and heteroskedasticity (heteroscedasticity).

If the model has spared from the problem of best ARDL model, with optimal lag, selected based on Akaike Info Criterion (AIC) with the results of the best research model is ARDL (1, 1, 1, 1, 1, 0, 1,0). Based on the AIC selection, the best ARDL model for the research model with a value of R-Squared Adjusted of $99.9 \%$ is the variable variation bound LNGDP can have explained by each of the independent variables of the selected ARDL model. Table 2 shows the result of the ARDL equation for the variable examined.

Table 1. The Result of Stationary Test

\begin{tabular}{ccc}
\hline Series & P-Value on the data level & 1 $^{\text {st }}$ Difference \\
\hline LNGDP & 0.2057 & 0.0000 \\
LNEXP & 0.565 & 0.0000 \\
LNDOMDEBT & 0.6035 & 0.0000 \\
LNCOC & 0.1375 & 0.0000 \\
LNGE & 0.3788 & 0.0000 \\
LNGOVDEBT & 0.5266 & 0.0000 \\
LNGOVEXP & 0.1349 & 0.0000 \\
LNIMP & 0.3964 & 0.0000 \\
\hline
\end{tabular}

From the short-term ARDL forecast results, we can see that the most potent influence of macroeconomic variables in this study is the first lag of GDP itself, which positively impacts current GDP increases. It can be interpreted that the increase of economic growth by $1 \%$ in the previous quarter had a positive and significant impact on the current aggregate GDP of $0.31 \%$. The findings are following the research results by (Ning et al., 2019). Furthermore, this model can also explain some critical variables and GPD that is Variable LNEXP (-1), which has a significant positive impact of $0.029 \%$. However, LNCOC (-1) has a negative effect by-0.025\%, and these results were incompatible with the research results by Azam et al. (2017) and Mauro (1995). Government debts, LNGOVDEBT (-1), also had a negative impact of-0076\%, in line with research Scott-Joseph \& Turner (2019). Government expenditure, LNGOVEXP (-1), has a positive impact of $0.0014 \%$ in increasing growth in line with research results by Amusa (2019), Sasmal (2016), Scott-Joseph \& Turner (2019), Chotia (2018), da Rocha $\&$ Saes (2018), the imported variable (LNIMP) has a positive impact of $0.022 \%$ in line with the Dawson (2006) research results. 
Table 2. ARDL test result model, selected with $\operatorname{ARDL}(1,1,1,1,1,0,1,0)$

\begin{tabular}{ccccc}
\hline Variable & Coefficient & Std. Error & t-Statistic & Prob. $^{*}$ \\
\hline LNGDP (-1) & 0.311970 & 0.097665 & 3.194267 & 0.0024 \\
LNEXP & -0.017467 & 0.012697 & -1.375677 & 0.1747 \\
LNEXP (-1) & 0.029279 & 0.010173 & 2.878190 & 0.0058 \\
LNDOMDEBT & -0.003521 & 0.026403 & -0.133365 & 0.8944 \\
LNDOMDEBT (-1) & 0.037758 & 0.023780 & 1.587819 & 0.1183 \\
LNCOC & 0.013692 & 0.010276 & 1.332496 & 0.1884 \\
LNCOC (-1) & -0.025563 & 0.011535 & -2.216036 & 0.0310 \\
LNGOVDEBT & 0.038169 & 0.033790 & 1.129575 & 0.2637 \\
LNGOVDEBT (-1) & -0.076733 & 0.031318 & -2.450124 & 0.0176 \\
LNGE & -0.015102 & 0.014008 & -1.078131 & 0.2859 \\
LNGOVEXP & 0.001086 & 0.000668 & 1.624881 & 0.1101 \\
LNGOVEXP (-1) & 0.001443 & 0.000630 & 2.291957 & 0.0259 \\
LNIMP & 0.022014 & 0.006540 & 3.366291 & 0.0014 \\
C & 22.67361 & 3.197932 & 7.090085 & 0.0000 \\
@ & 0.008286 & 0.001173 & 7.065364 & 0.0000 \\
\hline
\end{tabular}

Next, we see the long-term estimated result of this ARDL model. The first step to determining the long-term estimate is to use the Akaike information criterion (Top 20 models) available in Figure 2. The best value of the model is at the AIC score -7.927436 with ARDL $(1,1,1,1,1,0,1,0)$, which is suitable for lag one fit to be used for all variables.

The next step is doing a bound test. A fundamental assumption for the ARDL Bounds Testing approach is that the estimation model's errors must be serially independent and model dynamically stable. Diagnostic checks verify that the model is no longer serially correlated and is also dynamically stable. Tests of serial correlation have been conducted using the Breusch-Godfrey LM TEST, while the CUSUM test was used to verify the stability of the model. Based on these diagnostic tests' suitable outcomes, we proceed with the estimation of the long-run equilibrium relations among the variables. 
Figure 2. Akaike Information Criteria

Graph 3 Akaike Information Criteria (top 20 models)

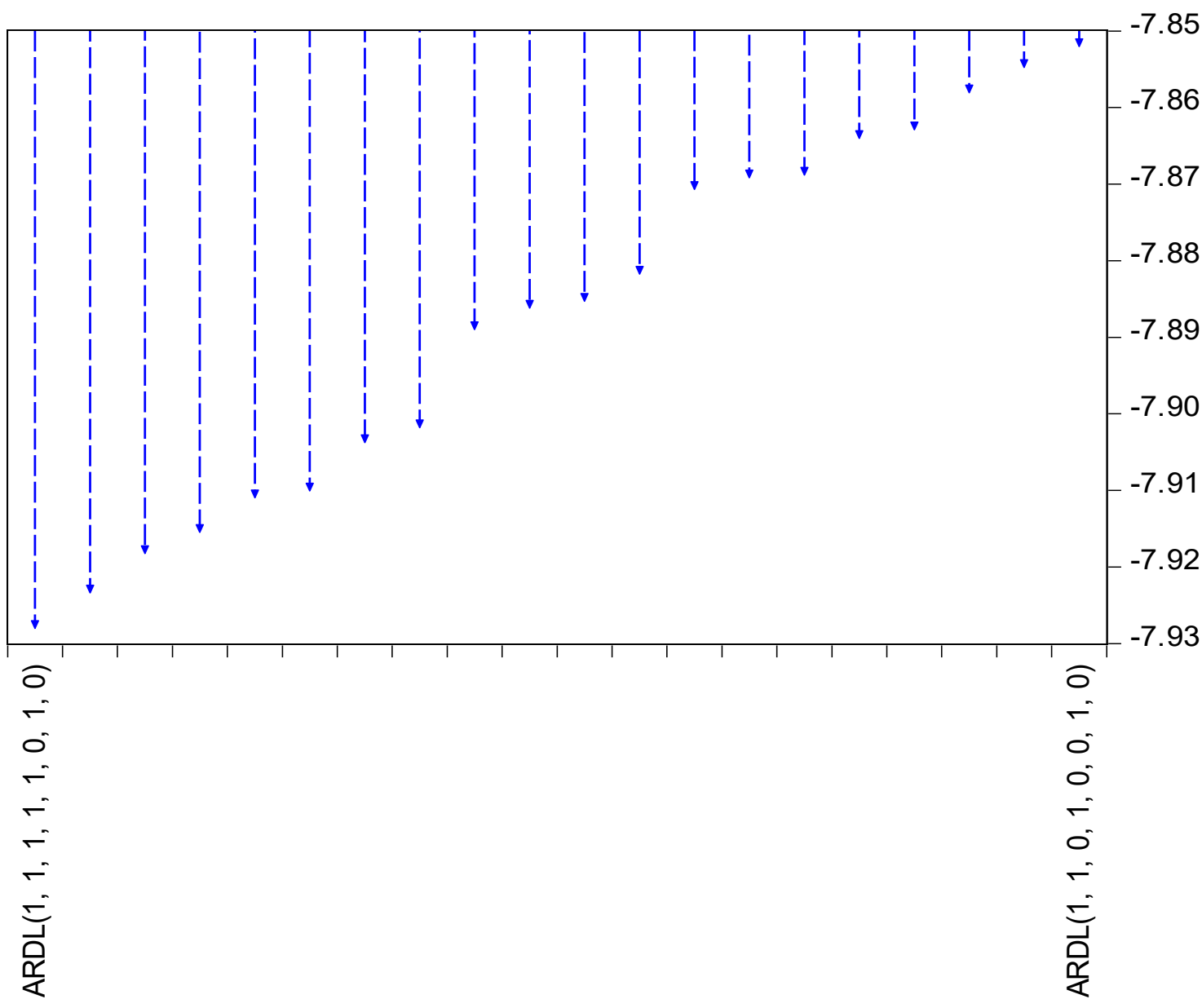

Table 3. Bound Test Result

\begin{tabular}{ccccc}
\hline \multicolumn{2}{c}{ F-Bounds Test } & \multicolumn{3}{c}{ Null Hypothesis: No levels relationship } \\
\hline Test Statistic & Value & Sig. & $\mathrm{I}(0)$ & $\mathrm{I}(1)$ \\
F-statistic & 8.985904 & $10 \%$ & 1.92 & 2.89 \\
$\mathrm{k}$ & 7 & $5 \%$ & 2.17 & 3.21 \\
& & $2.5 \%$ & 2.43 & 3.51 \\
& & $1 \%$ & 2.73 & 3.9 \\
\hline
\end{tabular}

The F-Statistic value test proves that the F-Statistic value is 8.985904, much higher than the upper $(3,9)$ and lower bound $(2,73)$ test at $=1 \%$ it can have concluded there is cointegration between research variables (see Table 3). The next stage is a series of basis for analysis, while some problems in the violation of OLS assumptions include: Serial correlation, heteroskedasticity test, CUSUM test as follows, and error correction form (EC) coefficient diagnostic. 
From the Breusch-Godfrey Serial Correlation LM Test results in Table 4, it can have interpreted that the probability of the occurrence of a serial Correlated is not significant, so we accept the null hypothesis (there is no serial correlation), so that the ARDL equation can be declared free of serial correlation. The next requirement is to investigate whether the model is free from heteroskedasticity symptoms using the Breusch-Pagan-Godfrey Heteroskedasticity Test. Based on the ARDL model results, it was obtained insignificant P-value results at $=5 \%$ so that it can have declared the model does not occur heteroskedasticity symptoms.

Table 4. Results of Autocorrelation and Heteroskedasticity Test

\begin{tabular}{cccc}
\hline \multicolumn{4}{c}{ Breusch-Godfrey Serial Correlation LM Test } \\
\hline F-statistic & 0.793070 & Prob. F (1,52) & 0.3773 \\
Obs*R-squared & 1.021512 & Prob. Chi-Square (1) & 0.3122 \\
\hline & Heteroskedasticity Test: Breusch-Pagan-Godfrey & \\
\hline F-statistic & 1.720968 & Prob. F (14,53) & 0.0789 \\
Obs*R-squared & 21.25160 & Prob. Chi-Square (14) & 0.0954 \\
Scaled explained SS & 17.04997 & Prob. Chi-Square (14) & 0.2535 \\
\hline
\end{tabular}

To test the model with the stable condition, we have also tested CUSUM and the CUSUM Squares test with the model's results declared stable in the range of numbers below $=5 \%$ as Figure 3 .

Figure 3. Cusum Test and Cusum of Squares Test

Graph 4 Cusum Test

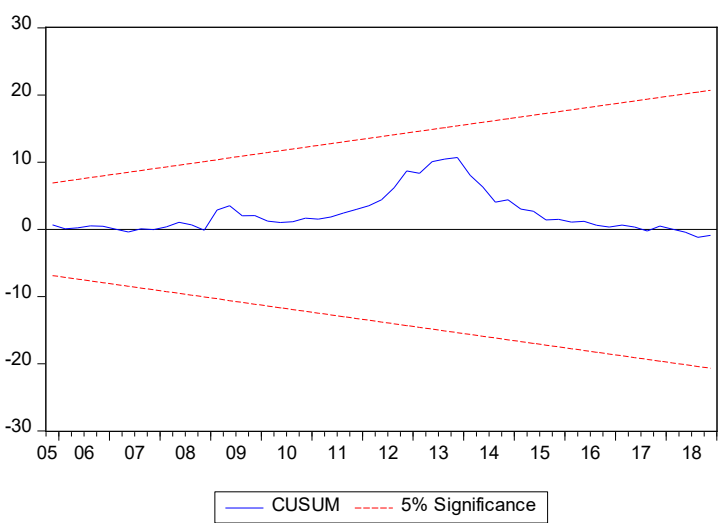

Graph 5 Cusum of Squares Test

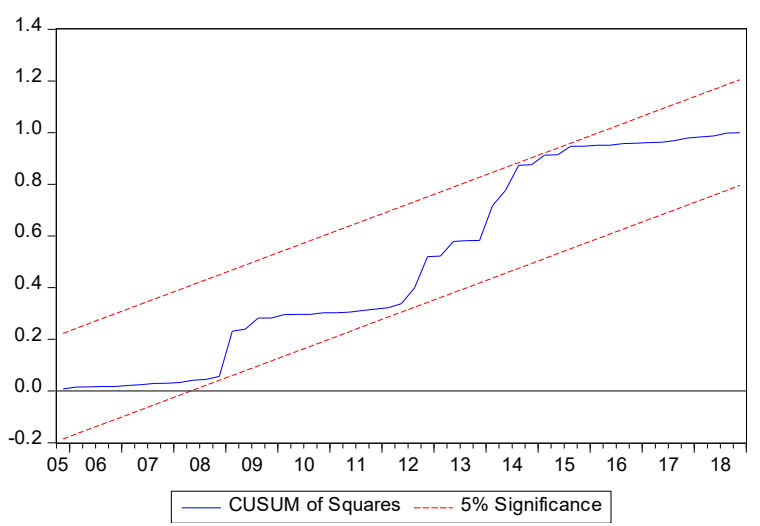

The next stage is seeing the results of Long-term estimate ARDL using coefficient diagnostics (see Table 5). Cointegration and long run form with LONG term EC equations $=$ LNGDP $-(0.0172 *$ LNEXP $+0.0498 *$ LNDOMDEBT-0.0173* LNCOC-0.0561* LNGOVDEBT-0.0219* LNGE + $0.0037 *$ LNGOVEXP $+0.0320 *$ LNIMP) results as follows: 
Table 5. Long-Term Estimated Results Using Coefficient Diagnostics

\begin{tabular}{ccccc}
\hline Variable & Coefficient & Std. Error & t-Statistic & Prob. \\
\hline LNEXP & 0.017167 & 0.017405 & 0.986353 & 0.3284 \\
LNDOMDEBT & 0.049761 & 0.030447 & 1.634337 & 0.1081 \\
LNCOC & -0.017253 & 0.006169 & -2.796792 & 0.0072 \\
LNGOVDEBT & -0.056050 & 0.037636 & -1.489290 & 0.1423 \\
LNGE & -0.021950 & 0.019372 & -1.133059 & 0.2623 \\
LNGOVEXP & 0.003676 & 0.001332 & 2.760202 & 0.0079 \\
LNIMP & 0.031996 & 0.009010 & 3.551061 & 0.0008 \\
\hline
\end{tabular}

From the results of the model in Table 5, the estimation can have noted that only the LNCOC variable has a negative and significant effect on GDP of $-0.017 \%$. The other variables such as LNGOVEXP, and LNIMP have a have an enormous impact with the coefficient of every $0.0036 \%$ and $0.031 \%$ of the extent of $1 \%$ GDP. While variables LNEXP, LNDOMDEBT, LNGOVDEBT, LNGE no significant effect on the long-term period. The final stage in the analysis and discussion using the ARDL model specifies error correction form (EC) coefficient diagnostic. The calculation result of our model related EC is negative 0.688030 , which means imply that deviation from the long-term growth rate in the GDP rate is corrected by $0.68 \%$ by following a period.

\section{Conclusion}

In Indonesia's context, in the period $2002 \mathrm{q} 4$ to $2018 \mathrm{q} 4$, in the condition of shortterm, most influential factor runs of economic growth supported by the first lag GDP itself. In addition to increasing economic growth, the first lag export and government expenditures are also playing an essential role with significant effect. However, several factors are also significant but have a negative effect; the factor controls corruption and government debt. Control of corruption has probably not had positively responded, and the magnitude of government debt can also reduce economic growth because there are debt and interest burdens must have paid. While the long-term control of corruption is still correlated negatively and significantly, government spending still has a positive and significant effect. On the other hand, import has a positive significant coefficient effect on the long-term response to GDP.

Finally, according to the research results, researchers can advise the government to increase the budget of its infrastructure spending even by not increasing the amount of debt significantly and raising the tax. That program could have done by increasing domestic and foreign capital participation in an export-oriented industrialization program by utilizing the spillover from the technology of foreign financier companies. This policy may be successful for an extended period because there are capital placement and increased 
workforce capacity. However, on the other end of the industrialization process, economic growth improves so that governments get a significant return on tax amount and can ultimately reduce the amount of domestic and government debt because, In the long term, it is bad for economic growth.

\section{References}

Afonso, A., \& Aubyn, M. S. (2019). Economic Growth, Public, and Private Investment Returns in 17 OECD Economies. Portuguese Economic Journal, 18(1), 47-65.

Aizenman, J., \& Marion, N. P. (1993). Macroeconomic Uncertainty and Private Investment. Economics Letters, 41(2), 207-210.

Akram, N. (2015). Is Public Debt Hindering the Economic Growth of the Philippines?. International Journal of Social Economics, 42(3), 202-221.

Amidu, A. R. (2016). The Causal Relationship Between Private Housing Investment and Economic Growth. International Journal of Housing Markets and Analysis, 9(2), 272-286.

Amusa, K. (2019). The Effectiveness of Government Expenditure on Economic Growth in Botswana. African Journal of Economic and Management Studies, 10(3), 368-384.

Atabaev, N., Ganiev, J., \& Alymkulova, N. (2018). Crowding-out (or-in) Effect in Transition Economies: Kyrgyzstan Case. International Journal of Development Issues, 17(1), 102-113.

Azam, M., Khan, A. Q., \& Bakhtyar, B. J. P. (2017). Surveying Sources of Economic Growth: Empirical Evidence From Malaysia. Problems and Perspectives in Management, 15(4), 114-123.

Cavalcanti, C. B., Marrero, G. A., \& Le, T. M. (2014). Measuring the Impact of DebtFinanced Public Investment. Policy Research Working Paper No. 6766. Washington: World Bank.

Chotia, V. (2018). Infrastructure Financing and Economic Growth in India: an Empirical Investigation. Journal of Financial Management of Property and Construction, 23(3), 258-273.

Da Rocha, F. V., \& Saes, M. S. M. (2018). Private Investment in Transportation Infrastructure in Brazil: The Effects of State Action. Revista de Gestão, 25(2), 228-239.

Dawson, J. W. (2006). Regulation, Investment, and Growth Across Countries. Cato Journal, 26(3), 489-509.

Deok-Ki Kim, D., \& Seo, J. S. (2003). Does FDI Inflow Crowd Out Domestic Investment in Korea?. Journal of economic studies, 30(6), 605-622.

Dreger, C., \& Reimers, H. E. (2016). Does Public Investment Stimulate Private Investment? Evidence for the Euro Area. Economic Modelling, 58, 154-158.

Erenburg, S. J. (1993). The Real Effects of Public Investment on Private Investment. Applied Economics, 25(6), 831-837. 
Greene, J., \& Villanueva, D. (1991). Private Investment in Developing Countries: an Empirical Analysis. Staff papers, 38(1), 33-58.

Khanna, R., \& Sharma, C. (2018). Do Infrastructure and Quality of Governance Matter for Manufacturing Productivity? Empirical Evidence from The Indian States. Journal of Economic Studies, 45(4), 829-854. https://doi.org/10.1108/JES04-2017-0100.

Mauro, P. (1995). Corruption and growth. The Quarterly Journal of Economics, 110(3), 681-712. https://doi.org/10.2307/2946696.

Murova, O. (2017). Public Investments, Productivity, and Economic Growth. International Journal of Productivity and Performance Management, 66(2), 251-265.

Muthu, S. (2017). Does Public Investment Crowd-out Private Investment in India. Journal of Financial Economic Policy, 9(1), 50-69.

Nguyen C. T. (2018). The Impacts of Public Investment on Private Investment and Economic Growth. Journal of Asian Business and Economic Studies, 25(1), 15-32.

Ning, Y., Xu, G., \& Long, Z. (2019). What Drives Venture Capital Investments in China?. Chinese Management Studies, 13(3), 574-602. https://doi.org/10.1108/CMS07-2017-0193.

Pesaran, M. H., Shin, Y., \& Smith, R. J. (2001). Bounds Testing Approaches to the Analysis of Level Relationships. Journal of Applied Econometrics, 16(3), 289-326.

Romer, P. M. (1994). The Origins of Endogenous Growth. Journal of Economic Perspectives, $8(1), 3-22$.

Sabir, S. (2019). Fiscal Policy, Institutions, and Inclusive Growth: Evidence from The Developing Asian Countries. International Journal of Social Economics, 46(6), 822837. https://doi.org/10.1108/IJSE-08-2018-0419.

Sabry, M. I. (2015). Good Governance, Institutions, and Performance of Public, Private Partnerships. International Journal of Public Sector Management, 28(7), 566-582. https://doi.org/10.1108/IJPSM-01-2015-0005.

Sasmal, R. (2016). Public Expenditure, Economic Growth, and Poverty Alleviation. International Journal of Social Economics, 43(6), 604-618. https://oi.org/10.1108/ IJSE-08-2014-0161.

Scott-Joseph, A., \& Turner, T. F. (2019). Does the Composition of Government Expenditure Matter for Eastern Caribbean Economies' Long-run Sectoral Output Growth?. International Journal of Development Issues, 18(1), 2-14. https://doi. org/10.1108/IJDI-01-2018-0011.

Shrestha, M. B., Bhatta, G. R. (2018). Selecting appropriate methodological framework for time series data analysis. The Journal of Finance and Data Science, 4(2), 71-89.

Spilimbergo, A., Symansky, S., Blanchard, O., \& Cottarelli, C. (2008). Fiscal Policy for the Crisis. IMF Staff Position Note, SPN/08/01. Washington: International Monetary Fund. 
Voss, G. M. (2002). Public and Private Investment in the United States and Canada. Economic Modelling, 19(4), 641-664. https://doi.org/10.1016/S0264-9993(00)00074-2.

Zhang, D. (2015). Public Investment in Agricultural R\&D and Extension. China Agricultural Economic Review, 7(1), 86-101. https://doi.org/10.1108/CAER-052014-0052. 